\title{
INDUSTRI MEDIA BUDAYA POPULER: ANALISIS SEMIOTIKA PEIRCE PADA DRAMA KOREA START UP
}

\author{
Anggana Aletta Bimantoro, Rizki Anindia Putri, Marisa Puspita Sary \\ Universitas Negeri Jakarta
}

\begin{abstract}
The focus of this research is the meaning and meaning behind the Korean 'start up' scene. The scene is the scene used to represent Korean culture. The purpose of this research is to know then the popular culture of Korea. Available representation may help interpretation of viewer starting up Korean drama impressions. The approach used was a qualitative approach with a semiotics study of Pierce. Semiology analysis based on sign objects as ICONS, symbols, and also indexes. This study has shown that the ICONS portrayed by drakor startup are the shooting sites used in the sandbox and the hangang river. Both are known to be iconic sites in South Korea. Then the index seen in the startup film is seo dal mi performing a ritual of asking for access to the automatic testing of the worthiness of the car that seo dal mi created with the company that was founded with her sister. Finally, there is a symbol, a symbol embedded in drakor startup, the holiday celebration of chuseok. This festival is just like the typical eid day. The chuseok festival was intended as a token of thanks to god for the harvest it had obtained.
\end{abstract}

\section{Keywords}

Korean Wave, Culture, Industrian Media

Correspondence Contact

alettabimantoro@gmail.com

\section{PENDAHULUAN}

Diketahui bahwa industri media telah berkembang secara pesat dan arus media nya berubah. Bahkan untuk mengakses informasi sudah menjadi hal yang mudah bagi masyarakat, dengan didukung media elektronik yang semakin canggih. Industri media massa telah menyajikan keanekaragaman produk - produk budaya melalui dunia perfilman, dunia musik, dunia entertainment dan dunia olahraga. Dengan waktu yang singkat, produk tersebut digunakan oleh masyarakat tanpa batas sebagai teks budaya dan akan menghadirkan kelompok kelompok penggemar. Kelompok penggemar biasanya disebut dengan fans. Kelompok tersebut mengkonsumsi produk budaya yang telah disajikan tanpa batas sebagai konstruksi budaya dan identitas sosial mereka. Industri media era 4.0 ini berkaitan dengan pengaruh global yang melakukan penyebaran media didukung oleh faktor media massa dan media sosial (Simbar, 2016)

Industri media massa yang berubah kini menghadirkan beberapa platform. Platform yang menyeluruh semua bidang. Termasuk salah satunya platform media streaming film atau drama. Pada zaman sekarang, untuk menonton film atau drama tidak perlu lagi melalui bioskop atau televisi atau bahkan kita harus membeli CD/DVD terlebih dahulu agar dapat menonton film. Hal tersebut dirasa kurang efektif jika ingin menonton dengan mudah. Apalagi di tahun 2020 sedang dilanda keadaan yang sulit yaitu virus corona banyak memakan korban jiwa sehingga masyarakat dihimbaukan untuk beraktivitas di rumah saja. Kini streaming film tersedia di website atau aplikasi disney hotstar, netflix, iflix, dan masih banyak lagi. Selain mendapat keefektifan waktu, website dan aplikasi tersebut sangat praktis digunakan. Konsep latar belakang website dan aplikasi diciptakan adalah bagi masyarakat umum yang ingin menonton film atau drama bisa mengakses kapan saja, bahkan bisa menonton apapun tanpa 
batas (Wibowo, 2018). Platform streaming film ini dinilai baik dan dapat diterima oleh masyarakat, karena dianggap sebagai wadah industri film. Bahkan di kondisi pandemi saat ini, banyak industri film yang menyiarkan karya nya melalui platform tersebut. Sehingga dapat mempengaruhi perkembangan teknologi informasi arus globalisasi saat ini

Korean Wave merupakan fenomena berkembangnya budaya korea yang mengakibatkan dampak yang berpengaruh di kebiasaan dan kehidupan sehari-hari khususnya generasi muda dan remaja. Korean Wave terjadi juga karena masyarakat luas menerima budaya korea yang berkembang pesat secara positif sehingga besarnya antusiasme publik terhadap Korean Wave di Indonesia sudah bukan merupakan hal yang aneh lagi. Popularitas Korean Wave atau biasa disebut dengan Hallyu meliputi drama, film, hingga musik (Asrori \& Supriadianto, 2019). Itu semua dikemas dengan menarik untuk menampilkan budaya-budaya korea sehingga para penikmatnya pun selalu dibuat ketagihan untuk menyaksikannya.

Berbicara tentang drama korea, terdapat dua genre. Genre pertama memiliki sedikit episode sedangkan genre utama yang kedua berisi sejarah biasa disebut saeguk (Sari, 2018). Saat ini ada drama yang sangat terkenal dan banyak diperbincangkan oleh publik yaitu drakor berjudul Start-Up yang berkisah tentang seorang pemilik usaha bernama Seo Dal Mi, seorang mahasiswi yang bekerja paruh waktu dan punya mimpi untuk menjadi seperti Steve Job. Setelah drop out dari kampusnya, Dal Mi pun ingin membangun perusahaannya sendiri dan membutuhkan biaya 90 ribu dolar AS sebagai modal usaha. Selain bercerita tentang Dal Mi, drakor ini juga menceritakan tentang Nam Do San, seorang pria pendiri startup bernama Samsan Tech. Sayangnya, perusahaannya tak pernah menguntungkan sehingga berdampak buruk pada reputasinya sebagai pengusaha. Kemudian, ada kisah dari seorang pengusaha lain bernama Han Ji Pyeong , seorang pimpinan SH Venture Capital yang berkeinginan mendirikan startup untuk melunasi hutang. Ia memiliki keahlian investasi yang tinggi sehingga dijuluki Gordon Ramsay dari Korea. Terakhir, CEO Won In Jae. Ia dikenal dan dikagumi oleh banyak orang karena cerdas, cantik, dan kaya. Namun, latar belakang keluarganya malah melemahkan reputasinya. Ia berusaha bangkit dan membangun kesuksesannya sendiri dengan mendirikan sebuah startup.

Penelitian terdahulu yang memiliki analisis pendekatan semiotika peirce (venessa agusta, 2016) dengan judul "Industri media dalam budaya populer, kajian semiotika peirce pada drama korea saranghae, I LOVE U" membahas mengenai arti adegan drama korea saranghae I LOVE U dengan membentuk tahapan strategi komunikasi yang memperkenalkan budaya korea. Hasil dari penelitian ini adalah menjelaskan bahwa terdapat makna yang nyata dalam drama korea saranghae I LOVE U, makna tersebut menunjukkan budaya populer dalam korea.

Selain itu, terdapat penelitian sebelumnya yang memiliki konsep korean wave dengan penulis (Ri'aeni, 2019) yang berjudul Pengaruh Budaya Korea (K-POP) Terhadap Remaja di Kota Cirebon membahas mengenai tradisi budaya dan gaya hidup korea berkembang sangat cepat dan telah menyebar secara global hampir ke seluruh dunia salah satunya Indonesia.

Dengan penelitian terdahulu yang sama sama membahas konsep korean wave, dengan melalui pendekatan semiotika peirce membuat peneliti ingin melakukan research tentang perkembangan budaya korean wave lalu dilandasi pendekatan semiotika peirce untuk menganalisis sebuah makna dalam drama korea Start Up yang sedang hits. Sehingga judul 
yang peneliti dapati yaitu "Industri media budaya populer analisis semiotika peirce pada drama korea Start Up"

\section{KAJIAN TEORITIK}

\section{Industri Media}

Pada awal berkembangnya ilmu komunikasi, media massa diasumsikan sebagai wadah komunikasi bertukar informasi dengan menyampaikan pesan, untuk mendapatkan feedback yang baik namun bersifat tertunda. Seperti contoh didapati acara talkshow atau iklan lainnya di televisi, atau melalui massa media online.Beberapa komponen yang dapat diperhatikan melalui perkembangan dengan kehadiran banyaknya jenis media yang udah lama berkembang, perkembangannya berhubungan dengan teknologi informasi dan komunikasi, dan perkembangan persatuan teknologi yang berakibat munculnya berbagai macam industri media baru.Industri media massa didefinisikan sebuah perkembangan industri yang kreatif dengan sesuai kebutuhan manusia dibidang pengetahuan, seni dan hiburan (Ri'aeni, 2019). Tentunya semakin meluas kebutuhan manusia, industri media pun ikut berkembang. Industri media massa dalam pergerakannya harus diperhatikan inovasi apa yang ingin dimunculkan dalam dunia globalisasi ini dengan begitu tidak luput dari kreativitas yang tinggi. Seperti film hanya biasanya dapat dinikmati lewat bioskop kini ada aplikasi khusus untuk masyarakat umum menonton film tanpa batas. Industri kreatif juga disebut dengan industri budaya, adanya budaya Indonesia serta tradisi nya yang unik dapat dijadikan sebagai sumber inspirasi industri untuk berkreativitas. Industri media dapat dikatakan media komunikasi massa, yang bersifat satu arah yang dapat mengubah pola pikir masyarakat (nadie, 2018).

Semiotika peirce

Semiotika adalah suatu analisis untuk mengkaji sebuah simbol yang memiliki makna pada peristiwa yang dianalisis. Semiotika seharusnya mempelajari bagaimana masyarakat mencari makna hal - hal tertentu. Semiotika memahami makna persoalan sebagai skema jalinan kausalitas yang terdapat bagian - bagian latar (Seto Wahjuwibowo, 2018). Pada umumnya, sebuah usaha untuk mencoba sesuatu yang tidak pernah dirasakan, sesuatu yang perlu dianalisis lebih dalam sehingga dapat disebut sebagai analisis semiotika yang bisa mendapatkan sebuah arti termasuk dari hal-hal yang tidak diketahui (Wibowo, 2013). Model triadik Peirce menunjukkan tugas peran penting subjek dalam tahap pergerakan bahasa. Selain itu menunjukkan tiga bagian penting penyatuan tanda, yaitu sesuatu yang melakukan presentasi hal - hal lain atau disebut representamen, hal yang dijadikan bahan representasi atau objek dan interpretasi orang mengenai simbol yang bisa disebut interpretant (Dewi, 2013). Suatu tata pengetahuan ilmu, tata pendekatan dan bidang kajian ilmu semiotika menunjukkan keakraban yang dilakukan oleh akademisi, dan mahasiswa khususnya jurusan ilmu komunikasi (Wahjuwibowo, 2018).

\section{Korean Wave}

Seperti yang kita ketahui, demam budaya korea sudah menjalar ke berbagai dunia khususnya Indonesia. Kita mulai terbiasa melihat banyaknya masyarakat yang gemar belajar atau menggunakan bahasa korea, berpakaian mengikuti tren di korea, mendengarkan musik, mengikuti tren beauty, hingga menonton drama-drama yang diluncurkan negara ginseng tersebut. Hal itu terjadi salah satunya karena banyak bermunculan drama-drama korea di TV. 
Proses penyebaran budaya korea di dunia dikenal dengan istilah Hallyu atau Korean Wave. (Putra \& Jusnita, 2018). Dengan adanya Korean Wave dorongan masyarakat yang menerima demi mendalami bahasa negara ginseng meningkat.

\section{METODOLOGI (Capital, Cambria, 10pt)}

Metode yang dipakai di dalam penelitian yang kami lakukan adalah metode kualitatif yang dimana metode ini memakai latar ilmiah guna menafsirkan kejadian yang sedang terjadi. Banyak sekali metode yang terlibat dalam kualitatif. Dalam penelitian ini, kami menggunakan studi semiotika Pierce. Yang menjadi landasan semiotika komunikasi menurut pierce adalah peran subjek yang merupakan bagian vital dari proses perubahan bahasa. Pierce memiliki pandangan kalau sebuah tanda mempunyai arti atau makna yang mengalami perubahan tiada henti seperti proses penciptaan sebuah rangkaian interpretasi tanpa akhir (Fitria, 2017). Terdapat keunikan dari teori semiotika Pierce yaitu model triadic yang terdiri dari ground/representamen, object, interpretant. Terdapat 3 bagian dalam ground/representamen yaitu tingkat kualitas simbol, popularitas lambang, dan aturan penting yang ada dalam tanda (Sobur Alex, 2006 dalam Thibburruhany, 2019). Selanjutnya adalah object yang membagi lambang menjadi ikonik, indeks dan simbol. Terakhir yaitu interpretant, mengandung tanda multitafsir sesuai dengan persepsi serta pemikiran orang yang mengalaminya. Namun, ada tanda yang tidak dipersoalkan karena sudah mewakilkan kenyataan. Kemudian argumen, yang artinya tanda yang mengartikan alasan tertentu (Thibburruhany, 2019). Jadi, semiotika merupakan pengetahuan yang menganalisis simbol - simbol yang ada berada suatu objek. Pada artikel ini objek yang diteliti adalah Korean Wave yang diperkenalkan melalui drama Start Up.

Jenis data yang dipakai adalah data primer. Teknik pengumpulan data yang dipakai dengan pengumpulan dokumentasi yang ditemukan dari hasil analisis terkait drama Start Up, Data tersebut berisikan sinopsis terdiri dari (1) sinopsis drama Start Up. Melalui sinopsis, peneliti menganalisis alur cerita yang disoroti dalam drama tersebut. (2) Mengambil sebagian adegan - adegan drama Start Up dari platform streaming film. (3) Ulasan di sosial media atas drama Start Up. Ulasan ini dipakai peneliti untuk menambahkan data primer.

Langkah - langkah selanjutnya, peneliti melakukan analisis data. Analisis dilakukan dengan pendekatan studi semiotika peirce yang lebih mengarah pada simbol atau tanda sebagai ikon, indeks dan simbol.

\section{PEMBAHASAN}

\section{Ikon didalam Drama Start Up}

Unsur teori semiotika Peirce dipaparkan ikon sebagai bagian analisis terhadap drama Start Up. Ikon dengan pendekatan analisis semiotika peirce yang dilansir dari sumber pakarkomunikasi.com didefinisikan tanda yang memiliki rupa yang sama dengan objeknya sesungguhnya, bahwa tujuan dari ikon yaitu memaknai pesan wujud aslinya Dalam drama Start Up terdapat aksi adegan beserta settingan lokasi yang memperlihatkan bahwa ikon tersebut sangat terkenal di korea selatan. 


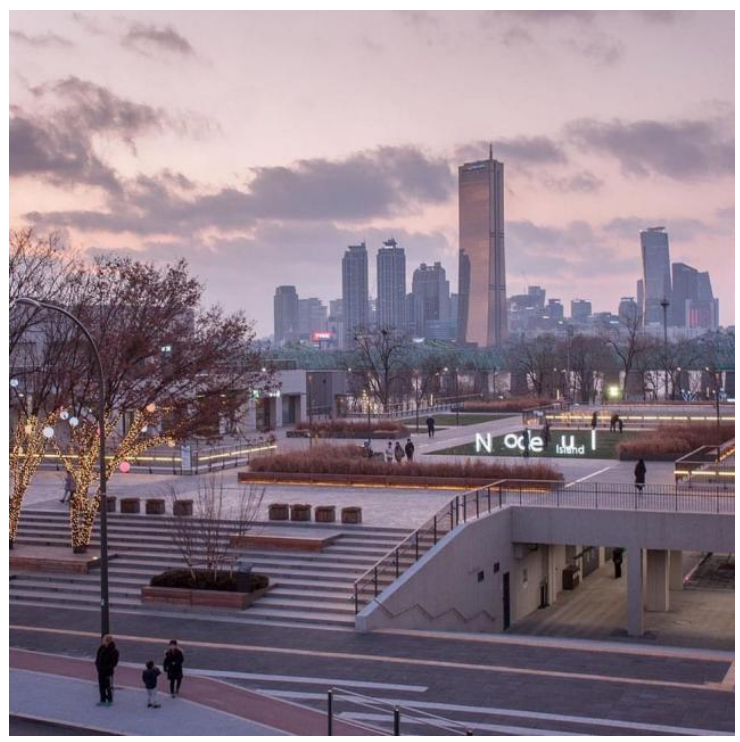

Gambar 1. Lokasi syuting Sand Box

sumber : https://www.instagram.com/p/CIVIH5OpU84/?igshid=9ye61v5skkaw

Pada gambar 1 digambarkan tempat yang menjadikan ikon dari drama Startup yang dikenal dengan Sandbox yang dimana tempat tersebut menjadi jawaban atas mimpi-mimpi para generasi muda yang ingin berbisnis atau membangun usaha rintisan. Tempat ini memiliki fasilitas serta kecanggihan teknologi yang dapat memadai. Dalam realita tempat ini berada di pulau Nodeul tepatnya di Seoul Korea Selatan, tempat ini bagaikan Silicon Valley yang terletak di Korea Selatan. Selain itu, para kru mendesain sedikit dengan menambahkan logo Sand Box di atasnya. Tempat ini menjadi ikonik karena biasanya sering diadakan pameran seni dan musik, apalagi di masa pekan dan hari libur nasional. Para pengunjung umumnya datang ke tempat wisata bertujuan ingin melihat dengan langsung tempat yang dijadikan lokasi syuting film atau drakor kebanyakan, sehingga menjadi tempat tersebut banyak kesan yang didapat (Asrori \& Supriadianto, 2019). Selain drama Start Up berdasarkan sumber cnnindonesia.com, acara televisi Korea yang berjudul "Running Man” juga memilih pulau Nodeul sebagai tempat lokasi syuting 


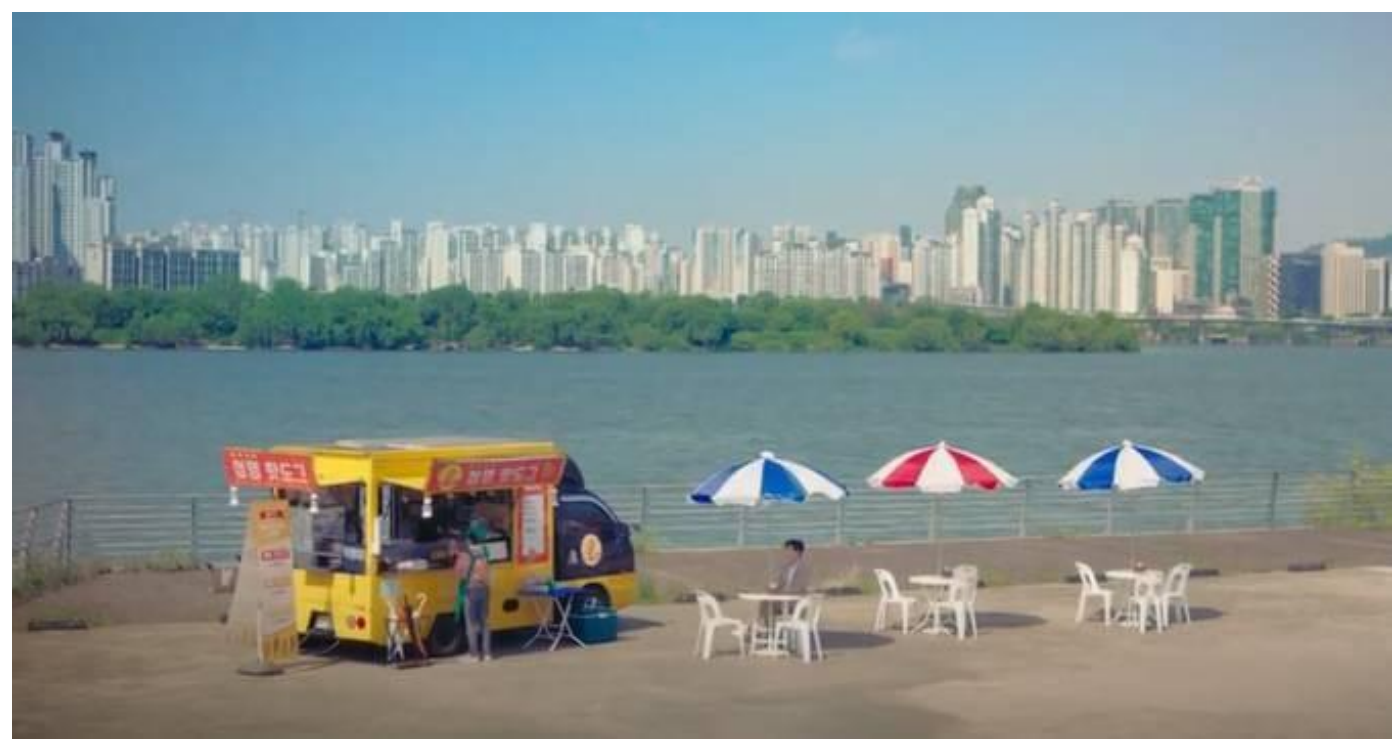

Gambar 2. Lokasi syuting truck corn dog nenek

sumber : https://images.app.goo.gl/me1aKNnpGnMVNoer6

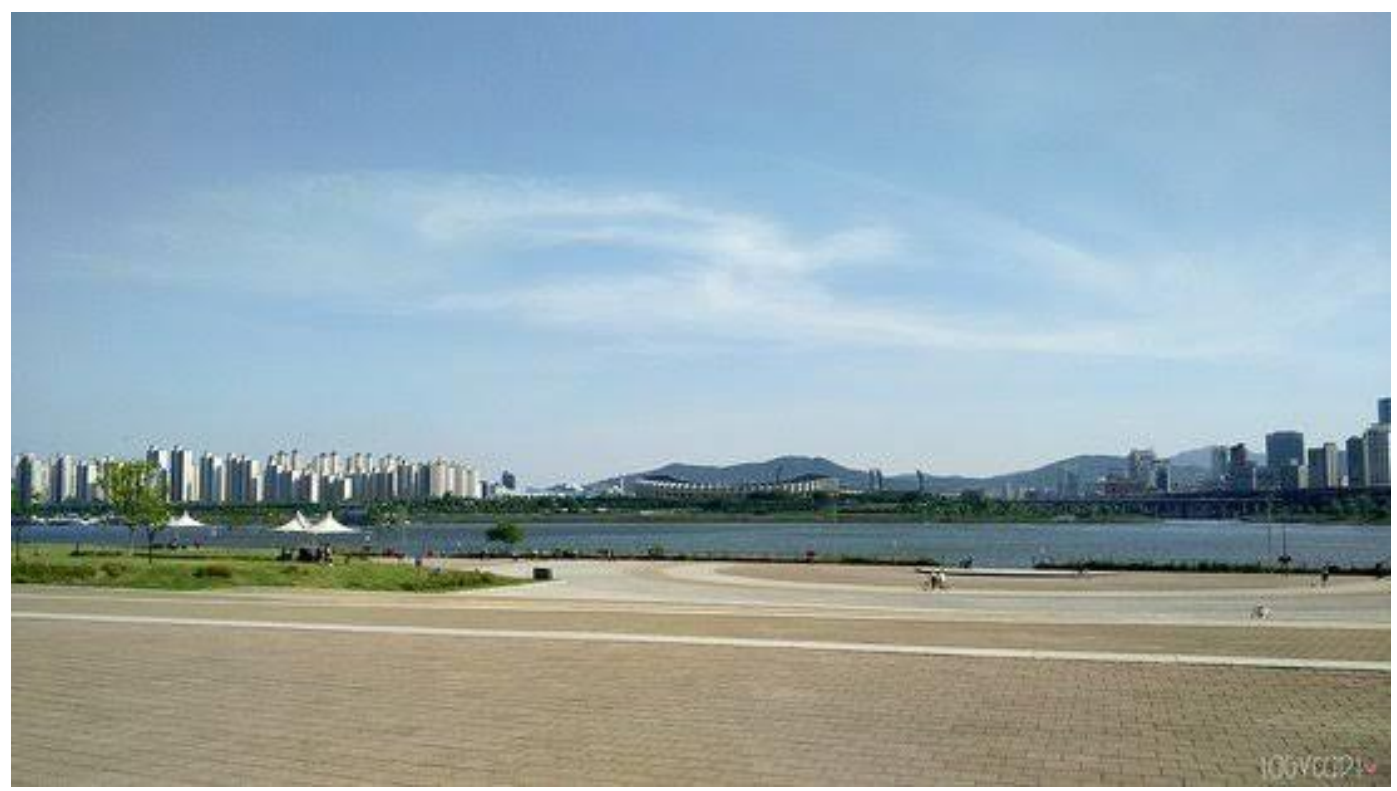

Gambar 3. Sungai Hangang

sumber : https://images.app.goo.gl/nkWgThQkaAcLToxJA

Temuan selanjutnya terdapat pada adegan ketika nenek Seo Dal Mi berjualan corn dog, pada gambar 1 terlihat sebuah truk milik nenek yang sedang berjualan corn dog. Sedangkan gambar 2 adalah lokasi syuting tempat nenek berjualan corn dog yaitu di taman Hangang Yeouido, Seoul. Dari olahraga sampai piknik bisa dilakukan di sini. Ketika akhir pekan, terdapat panggung musik yang digelar di panggung terapung. Kegiatan favorit di sini adalah jalan-jalan santai bersama pasangan saat matahari terbenam serta memandangi sungai Han. Pada malam hari juga tak kalah menarik, karena ada pertunjukkan air mancur dari atas jembatannya. 
Baik pulau Nodeul maupun sungai Hangang, keduanya adalah ikon tempat wisata di Korea. Ikon merupakan sebuah tanda yang terdapat dalam settingan lokasi syuting namun tidak langsung memiliki unsur interpretasi bahwa korea banyak tempat wisata hiburan. Drama Start Up membuat kedua lokasi syuting ini menjadi tempat yang wajib dikunjungi para penonton ketika berada di Korea Selatan. Ikon ini dipilih karena lokasi tersebut sebagai representasi tempat wahana hiburan

Semua gambaran ad egan dan lambang ikon dalam aksi adegan memiliki persamaan yaitu ingin menunjukkan tujuan lokasi wisata korea dan menunjukkan keindahan sebagian wisata yang ada di korea selatan, yaitu pulau Nodeul dan sungai Hangang. Setting lokasi tersebut dipilih sebagai representasi ikon negara Korea Selatan.

Indeks yang terlihat dalam drama Start Up terdapat pada episode 15 menunjukkan sebuah tradisi untuk mencapai sebuah pencapaian yang dilakukan Seo Dal Mi, seperti ritual.

Menurut Sobur, indeks adalah lambang yang memperlihatkan hubungan secara natural antara lambang dan petanda yang memiliki sifat hubungan kausalitas yang menuju pada kenyataan. Secara ringkas, indeks didefinisikan hubungan sebab akibat (Wulandari, 2020). Ritual yang diadakan oleh Seo Dal mi bertujuan untuk meminta diberi kelancaran tes uji coba kelayakan mobil otomatis yang dirakit oleh perusahaan nya bersama kakaknya. ritual tersebut dipercaya dapat membawa keberuntungan dan sudah dilakukan secara turun temurun oleh keluarga Seo Dal Mi.

\section{Simbol Pada Adegan Drama Start Up}

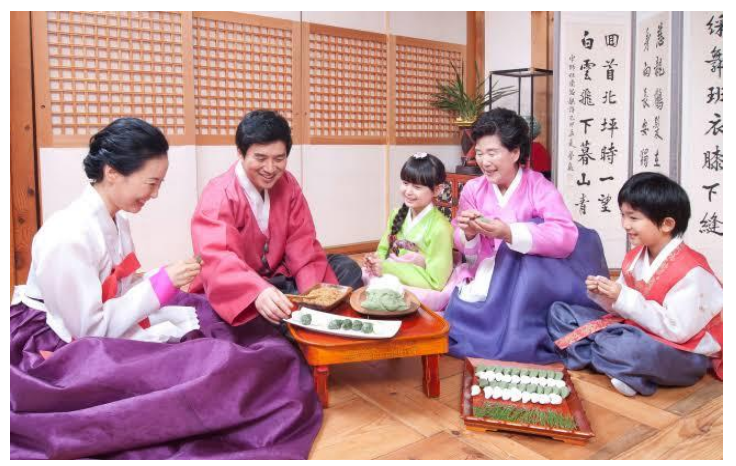

Gambar 4. Hari raya Chuseok

sumber : https://images.app.goo.gl/NvnTuPA1b2eJk2C37

Simbol merupakan lambang yang dijadikan suatu identitas atas dasar persetujuan persetujuan secara disengaja maupun tidak disengaja. (Thabroni, 2018). Simbol merupakan lambang yang mempunyai arti umum yang sudah menjadi tradisi oleh warga Korea Selatan adalah hari raya Chuseok. Adat ini dilaksanakan pada waktu pertengahan musim gugur guna mensyukuri hasil panen yang diperoleh. Fakta-fakta yang menarik terdapat di adat ini, contohnya adalah pulang kampung tepat saat Chuseok serta melewati liburan bersama keluarga. Selain itu terdapat pula semacam festival musim panen yang merupakan salah satu jenis hari raya Chuseok yang dilakukan dengan menunjukkan macam-macam pertunjukkan (kumparan,2020). Demikian ditunjukkan pada satu adegan drama Korea Start Up Seo Dal Mi sedang melakukan perayaan Chuseok dengan keluarganya sebagai tanda rasa mensyukuri dan berterima kasih terhadap Tuhan Yang Maha Esa atas pemberian hasil panen. 


\section{KESIMPULAN (Capital, Cambria, 10pt)}

Penelitian ini menganalisa dengan pendekatan semiotika peirce secara umum membahas memahami makna sebuah tanda atau simbol yang terjadi pada peristiwa. Teknik Pengumpulan data menggunakan dokumentasi drakor Startup. Kesimpulan pembahasan penelitian yang telah dilakukan, ada 3 poin penting dalam semiotika peirce. Yaitu ikon, indeks, dan simbol. Ikon yang digambarkan pada drakor startup, lokasi syuting yang digunakan berada di sandbox dan sungai hangang. Diketahui dua lokasi tersebut merupakan lokasi ikonik di korea selatan. Lalu indeks yang terlihat dalam film startup yaitu Seo Dal Mi melakukan ritual meminta diberikan kemudahan tes uji coba kelayakan mobil otomatis yang diciptakan oleh Seo Dal Mi bersama perusahaan yang didirikan bersama kakaknya. Yang terakhir ada simbol, simbol yang terpaparkan dalam drakor startup yaitu perayaan hari raya chuseok. perayaan ini sama seperti halnya dengan hari lebaran pada umumnya.Perayaan hari raya chuseok. Penelitian yang telah dilakukan semoga bermanfaat untuk praktisi, dan mahasiswa ilmu komunikasi terutama dalam menambah pengetahuan mengenai analisis semiotika peirce.

DAFTAR PUSTAKA (Capital, Cambria, 10pt)

JURNAL

Asrori, Y. W., \& Supriadianto, S. (2019). Hallyu dan Pengaruhnya pada Perkembangan Objek

Wisata Tematik Korea Selatan. Jurnal Pariwisata Terapan, 3(1), 76.

https://doi.org/10.22146/jpt.49278

Dewi, M. (2013). REPRESENTASI PAKAIAN MUSLIMAH DALAM IKLAN (Analisis Semiotika

Charles Sanders Peirce pada Iklan Kosmetik Wardah di Tabloid Nova). Profetik.

Fitria, R. (2017). Analisis Semiotika Charles Sanders Peirce dalam iklan Kampanye Pasangan Calon Gubernur dan Wakil Gubernur Provinsi Bengkulu Tahun 2015. MANHAJ: Jurnal Penelitian Dan Pengabdian Masyarakat, 5, 44-50.

Putra, A. A., \& Jusnita, R. A. E. (2018). Komunikasi dan Identitas Budaya Populer pada Komunitas Korea Lovers Surabaya. Jurnal Kajian Media, 2(1), 1-11.

https://doi.org/10.25139/jkm.v2i1.842

Ri'aeni, I. (2019). Pengaruh Budaya Korea (K-Pop) Terhadap Remaja Di Kota Cirebon.

Communications. https://doi.org/10.21009/communications.1.1.1

Sari, Y. (2018). Dampak Tayangan Drama Korea My Secret Romance Terhadap Akhlakul

Karimah (p. 44). Universitas Islam Negeri Raden Intan Lampung.

Simbar, F. K. (2016). Fenomena Konsumsi Budaya Korea Pada Anak Muda Di Kota Manado. Holistik.

Thibburruhany. (2019). Analisis Semiotika Charles S. Pierce terhadap Iklan Politik JokowiMa'ruf dan Prabowo-Sandi. Lentera, III, 21-39.

Wibowo, T. O. (2018). Fenomena Website Streaming Film di Era Media Baru: Godaan,

Perselisihan, dan Kritik. Jurnal Kajian Komunikasi.

https://doi.org/10.24198/ikk.v6i2.15623 
Wulandari, S. (2020). KAJIAN SEMIOTIKA CHARLES SANDERS PEIRCE: RELASI TRIKOTOMI (IKON, INDEKS DAN SIMBOL) DALAM CERPEN ANAK MERCUSUAR KARYA MASHDAR ZAINAL. Jurnal Ilmu Humaniora.

BUKU

nadie, 1. (2018). In media massa dan pasar modal : strategi komunikasi bagi perusahaan go public. jakarta: pustaka kaji.

Wahjuwibowo, I. S. (2018). Semiotika Komunikasi Aplikasi Praktis Bagi Penelitian dan Skripsi Komunikasi (3rd ed.). Mitra Wicana Media.

Wibowo, I. S. W. (2013). Semiotika Komunikasi Aplikasi Praktis Bagi Penelitian dan Skripsi Komunikasi (2nd ed.). Mitra Wicana Media.

\section{WEBSITE}

CNN Indonesia. 2020. Nodeul, 'Sepotong' Pulau Buatan Lokasi Sandbox di Star Up. cnnindonesia.com. Retrieved from https://www.cnnindonesia.com/gayahidup/20201211200815-269-581157/nodeul-sepotong-pulau-buatan-lokasi-sandboxdi-start-up

Kumparan. (2020). 5 Fakta Perayaan Chuseok, Hari Raya Warga Korea Selatan. Kumparan.com. retrived from https://kumparan.com/berita-hari-ini/5-faktaperayaan-chuseok-hari-raya-warga-korea-selatan-1uIi2MFE8RK/full

PakarKomunikasi. (2017). Teori Semiotika Charles Sander Peirce-sign-object-interpretant. PakarKomunikasi.com Retrived from https://pakarkomunikasi.com/teori-semiotikacharles-sanders-peirce

Thabroni, G. (2018). Semiotika: Komunikasi tanpa kata, pengertian simbol dan tanda. serupa.id.retrived from https://serupa.id/semiotika-pengertian-simbol-dan-tandatanda/ 